\title{
INFLAMMATION AND IMPACT OF VINCRISTINE AND ENTEROSORPTION USE IN CHEMICALLY INDUCED COLON CARCER IN RATS
}

\author{
O.I. Kachur, *L.S. Fira, P.H. Lykhatskyi \\ I. HORBACHEVSKY TERNOPIL NATIONAL MEDICAL UNIVERSITY, TERNOPIL, UKRAINE
}

Background. The increasing incidence of colon malignant tumors is one of the most urgent matters of contemporary medicine. In the study of carcinogenesis of the colon the attention is paid to the state of the body's immune system and activation of inflammatory processes in experimental animals.

Objective. The aim of the study was to estimate the level of markers of inflammation in the serum of experimental animals with chemically induced carcinogenesis and their dynamics in case of administration of the cytostatic Vincristine secondary to AUT-M carbon enterosorbent.

Methods. The study was performed on white male rats. Animals were modeled for colon cancer by administration of 1.2-dimethylhydrazine hydrochloride at a dose of $7.2 \mathrm{mg} / \mathrm{kg}$ body weight for 30 weeks. AUT-M enterosorbent was administered intragastrically daily during 7 and 21 days after modeling of carcinogenesis at a dose of $1 \mathrm{ml}$ of suspension (corresponding to $0.2 \mathrm{~g}$ of drug weight) per $100 \mathrm{~g}$ of animal body weight. The antitumor drug was administered to the animals with induced carcinogenesis intragastrically daily during 14 days at a dose of $0.23 \mathrm{mg} / \mathrm{kg}$ of body weight after a 21-day detoxification therapy. The activity of inflammatory processes was evaluated by the content of pro-inflammatory interleukin 6 and anti-inflammatory interleukin 4, $C$-reactive protein in the serum of experimental animals.

Results. It was established that introduction of 1.2-dimethylhydrazine hydrochloride in the rats caused changes in the cytokine profile and the content of C-reactive protein. In the affected animals an increase in the content of pro-inflammatory interleukin 6, C-reactive protein, as well as a decrease in the content of antiinflammatory interleukin 4 was evidenced in all periods of the study. AUT-M enterosorbent contributed to normalization of these parameters. The cytostatic Vincristine had a negligible effect on development of inflammatory processes in the studied animals.

Conclusions. In cases of induced carcinogenesis, an imbalance in the content of pro-and anti-inflammatory cytokines, an increase in the content of acute-phase C-reactive protein was established. The positive effect of the cytostatic Vincristine secondary to a previous detoxification therapy with AUT-M sorbent during a progressive development of inflammatory processes in the presence of modeled carcinogenesis was evidenced.

KEY WORDS: inflammatory processes; proinflammatory interleukins; anti-inflammatory interleukins; AUT-M sorbent; cytostatic Vincristine.

\section{Introduction}

Malignant neoplasms of the colon are still one of the urgent matters of contemporary medicine. Recently the incidence of colorectal cancer among young and middle-aged people has been increasing constantly [1].

It is established that the transformation of a normal cell into a malignant one is accompanied by a homeostasis disorders and changes in all types of metabolism. In the body of the tumour carrier, free radical processes activate, the integrity of plasma membranes is disturbed in cases of destructive changes. As the cancer develops, excessive toxins accumulate and endogenous intoxication intensifies. All these factors cause evolution of inflammatory reaction of the body [2,3].

*Corresponding author: L.S. Fira, PhD, DSC, Professor, Head of the Department of Pharmacy of the Academic and Research Institute of Postgraduate Education, I. Horbachevsky Ternopil National Medical University, Ternopil, Ukraine; e-mail: fira@ tdmu.edu.ua
Markers of the systemic inflammatory response in the evolution of carcinogenesis are the acute proteins: ceruloplasmin (CP), haptoglobin and especially C-reactive protein (CRP), cytokines.

C-reactive protein (CRP) is one of the most sensitive and early markers of the acute phase of the inflammatory process. An increase in the concentration of CRP in the serum evidences development of a pathological process and destructive changes in the body [4]. The synthesis of CRP of the acute phase of inflammation is triggered and regulated primarily by cytokines, namely IL-6, which is formed directly in the inflammatory focus and acts as a primary activator of genes involved in it and tumor transformation [5].

Due to the increasing frequency and prevalence of colorectal cancer in modern society, the issue of finding and researching effective 
and low-toxic cytostatics of plant origin is still topical.

Vincristine is a herbal cytostatic, it is an important component of the combined treatment regimen for malignant neoplasms. However, in the present literature there are some publications on the use of periwinkle alkaloids in the chemotherapeutic treatment of colorectal cancer [6].

Enterosorption therapy is one of the promising methods for control of inflammation. AUT-M carbon sorbent with a large specific pore area exhibits physicochemical properties of a sorbent substance capable of binding and excreting toxins of exogenous and endogenous origin $[7,8]$.

The research is aimed to evaluate the level of inflammation markers in the serum of experimental animals with chemically induced carcinogenesis and their dynamics with introduction of the cytostatic Vincristine secondary to AUT-M carbon enterosorbent.

\section{Methods}

The study was performed on 76 white male rats. The initial body weight of animals was 200-250 g. Simulation of carcinogenesis of the colon was carried out by subcutaneous weekly injection into the interscapular area of asymmetric 1.2-dimethylhydrazine (1.2-DMG, made by SIGMA-ALDRICH CHEMIE company, Japan) for 30 weeks. The carcinogen 1.2-DMG was previously diluted with isotonic sodium chloride solution, dose $7.2 \mathrm{mg} / \mathrm{kg}$ [9].

After modeling of the cancer process for 30 weeks, the affected animals underwent enterosorption therapy for 21 days. AUT-M carbon sorbent was administered intragastrally daily, daily dose $1 \mathrm{ml}$ of suspension (corresponding to $0.2 \mathrm{~g}$ of net weight of the drug) per $100 \mathrm{~g}$ of body weight of the animal [10].

The anticancer drug Vincristine was administered intragastrically daily at a dose of $0.23 \mathrm{mg} / \mathrm{kg}$ of animal body weight for 14 days, starting immediately after 7-month modeling of the cancer process and 21-day enterosorption therapy. The dose of cytostatics was chosen according to the instructions for use of the drug and taking into account sensitivity of the animals (recalculation was carried out according to Yu. R. Rybolovlev, 1979) [11].

The experimental animals were divided into 4 groups: group 1 - the control involved the animals administered with isotonic sodium chloride solution, group 2 - the animals affected by 1.2-DMG, group 3 - the animals affected by
1.2-DMG, managed by AUT-M enterosorbent for 21 days after a 30-week carcinogen administration, group 4 - the animals administered with the cytostatic Vincristine for 14 days after enterosorption therapy.

Euthanasia of animals was performed by bloodletting under thiopental-sodium anesthesia monthly for 7 months and on the $14^{\text {th }}$ and $21^{\text {st }}$ days of administration of the AUT-M enterosorbent after carcinogenesis modeling, as well as on the $14^{\text {th }}$ day after administration of the cytostatic Vincristine. The serum was used for studies.

All manipulations with experimental rats were performed following the rules in accordance with the European Convention for the Protection of Vertebrate Animals Used for Research and Other Scientific Purposes [12].

To study the development of inflammatory processes in cases of induced carcinogenesis of the colon the concentration of proinflammatory and anti-inflammatory interleukins in the serum of rats was determined by the ELISA test [13]. The content of C-reactive proteins was determined by immunoturbidimetric method [14].

The obtained experimental results were statistically processed by the method of variation statistics using a standard package of Statistica 6.0 statistical program [15]. The standard deviations, variance and other statistical parameters were determined, and the statistically significant differences were determined using Student's t-test. The differences were statistically significant at $p \leq 0.05$.

\section{Results}

Inflammatory reactions of the body are a non-specific part of the defense, the formation of which prevents the spread of the pathogen and is realized by attracting granulocytes, macrophages and lymphocytes to the site of inflammation. The first stage of such reactions is associated with the activation of pro-inflammatory cytokines. They provide chemotraction of the inflammatory cell [16].

In the dynamics of 1.2-DMG administration, the content of pro-inflammatory cytokine IL-6 in the serum of affected animals probably $(p \leq$ 0.05 ) increased during the $1^{\text {st }}$ month of 1.2-DMG administration (by $62 \%$ compare to the control group). Intermediate results point to similar changes: in 5 months of DMG affection (increased by $182 \%$ ) and in 7 months (by $251 \%$ ) of adenocarcinoma modeling (Fig. 1).

The corrective dose of the AUT-M sorbent helped to reduce the content of IL- 6 in the 


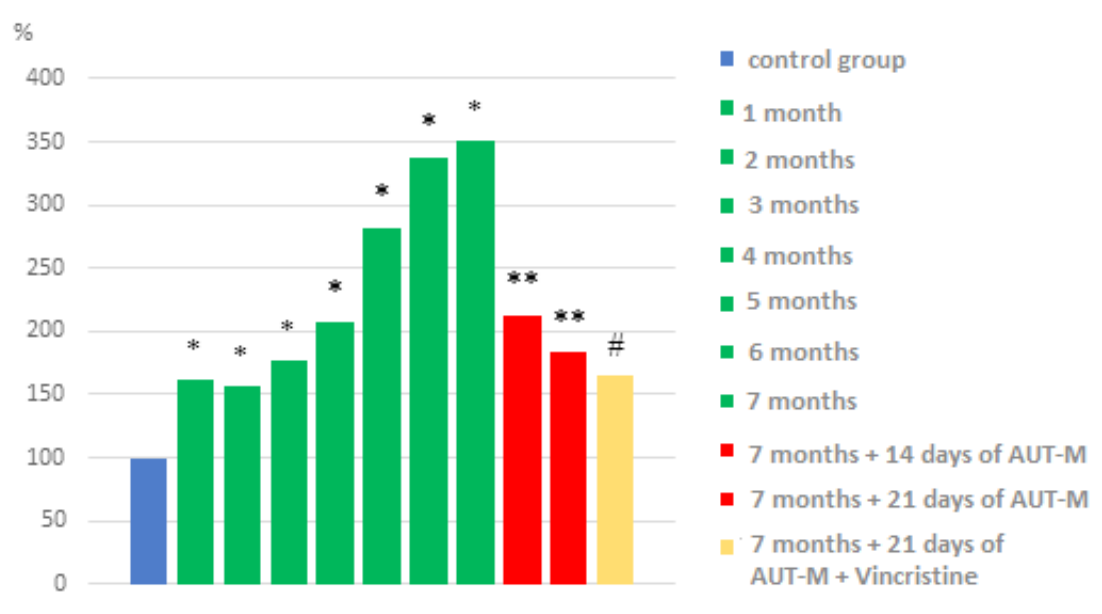

Fig. 1. The level of IL- 6 in the serum of rats in the dynamics of the affection by 1.2-DMG and after administration of AUT-M sorbent and cytostatic Vincristine, \%.

Notes: * - statistically significant difference between the parameters of the control group animals and the animals affected by 1.2-DMG; ** - statistically significant difference between the parameters of the carcinogenic animals and the animals administered with enterosorbent; $* * *$ - statistically significant difference between the parameters of carcinogenic animals after enterosorption therapy (for 21 days) and the animals administered with cytostatics (for 14 days); * - statistically significant difference between the parameters of carcinogenic animals (in 7 months) and the animals administered with cytostatic (for 14 days) secondary to enterosorption therapy (for 21 days).

serum of the affected animals. It was established that IL-6 probably decreased in the serum by $138 \%(\mathrm{p} \leq 0.05)$ after a 14-day sorbent therapy, the maximal changes were evidenced in 21 days of sorbent management (decreased by $168 \%$ ) compare to the same group of the affected animals.

Cytostatic correction performed for 14 days leads to a slight decrease in IL- 6 in the serum of rats. The studied parameter decreased by $186 \%$ in comparison with the affected animals.

Toxic affection of the animals during 30 weeks causes an imbalance of the cytokine profile in their body. The functional antagonists of pro-inflammatory IL-6 include anti-inflammatory IL-4. This cytokine has an antitumor effect; it is a strong growth factor for B-lymphocytes, which promotes their differentiation, activation and reproduction [17].

Statistically significant differences in the content of IL-4 were found later after beginning of 1.2-DMG administration. The rate decreased by $29 \%$ in 5 months of carcinogenesis modeling. After a 30-week DMG affection, the content of IL- 4 in the serum of the rats decreased by $45 \%$ compare to the control (Fig. 2).

After a 21-day detoxification therapy, the level of IL-4 increased by $30 \%$ compare to the group of animals with no detoxification therapy.

In the group of animals undergoing cytostatic therapy, an increase in the content of anti-inflammatory IL-4 by $35 \%$ was evidenced compare to the animals with carcinogenesis.
With administration of 1.2-DMG into the experimental animals, changes of acute phase proteins activity were evidenced. Thus, the content of CRP was likely to increase starting the third month of carcinogenesis modeling and exceeded the level of control in 1.5 times. A similar trend was proved in the subsequent affections, in 5 months after the beginning of the experiment, the content of CRP increased in 1.73 times, in 7 months - in 2.1 times compare to the control rats (Table 1 ).

The obtained results may indicate an intensification of the inflammatory process in the body of experimental animals affected by 1.2 DMG.

The detoxification therapy (for 21 days with the AUT-M sorbent) contributes to the probable decrease on this parameter in the serum of the affected animals. In 21 days of administration of this sorbent, the content of CRP decreased in 1.6 times compare to the group of affected animals.

During the chemotherapy treatment of the affected animals (with previous sorbent correction), a slight increase in the CRP content was evidenced. In 14 days of Vincristine administration, the parameter increased in 1.3 times compare to the animals modeled for colon carcinogenesis for 30 weeks.

Thus, a 30-week DMG affection of the rats caused an imbalance in the content of proinflammatory and anti-inflammatory cytokines with further development of inflammatory 


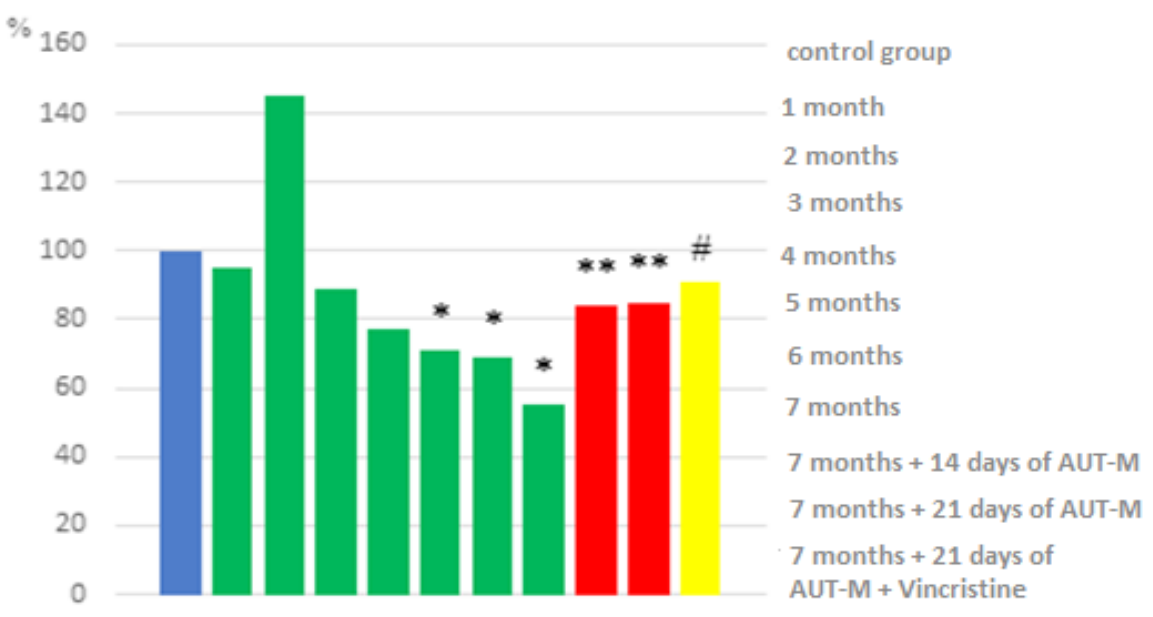

Fig. 2. The content of IL-4 in the serum of rats in the dynamics of the affection by 1.2-DMG and after administration of AUT-M sorbent and cytostatic Vincristine, \%

Notes: * - statistically significant difference between the parameters of the control group animals and the animals affected by 1.2-DMG; ** - statistically significant difference between the parameters of the carcinogenic animals and the animals administered with enterosorbent; $* * *$ - statistically significant difference between the parameters of the carcinogenic animals after enterosorption therapy (for 21 days) and the animals administered with cytostatics (for 14 days); * - statistically significant difference between the parameters of the carcinogenic animals (in 7 months) and the animals administered with cytostatics (for 14 days) secondary to enterosorption therapy (for 21 days).

processes that was confirmed by an increase in early marker of inflammation in the serum: C-reactive protein and interleukin 6 . The use of sorption therapy had a positive effect on inflammation in the body of rats throughout the experiment. No significant side effects after administration of the cytostatic Vincristine were evidenced.

\section{Discussion}

The search for effective methods of correction of oncological pathologies is topical issue of contemporary medicine. The use of low-toxic and affordable drugs is important. Our research on the efficacy of cytostatic Vincristine secondary to enterosorption therapy in cases of simulated carcinogenesis is proved by reduced

Table 1. The content of C-reactive protein in the serum of rats $(\mathrm{mg} / \mathrm{l})$ with induced oncogenesis and after administration of cytostatic Vincristine secondary to detoxification therapy, $(\mathrm{M} \pm \mathrm{m})$

\begin{tabular}{|l|c|}
\hline \multicolumn{1}{|c|}{ Animal group/duration of dimethylhydrazine affection } & Serum \\
\hline Control, $(n=6)$ & $2.45 \pm 0.18$ \\
\hline 1 month, $(n=7)$ & $2.78 \pm 0.21$ \\
\hline 2 months, $(n=7)$ & $3.15 \pm 0.29$ \\
\hline 3 months, $(n=7)$ & $3.66 \pm 0.34^{\star}$ \\
\hline 4 months, $(n=7)$ & $4.12 \pm 0.38^{*}$ \\
\hline 5 months, $(n=7)$ & $4.25 \pm 0.39^{*}$ \\
\hline 6 months, $(n=7)$ & $5.10 \pm 0.49^{*}$ \\
\hline 7 months, $(n=7)$ & $5.25 \pm 0.50^{*}$ \\
\hline 7 months of DMG + AUT-M (for 14 days), $(n=7)$ & $4.55 \pm 0.40$ \\
\hline 7 months of DMG + AUT-M (for 21 days), $(n=7)$ & $3.80 \pm 0.36^{* *}$ \\
\hline 7 months of DMG + AUT-M (for 21 days) + & $4.01 \pm 0.16^{\#}$ \\
\hline
\end{tabular}

Notes: * - statistically significant difference between the parameters of the control group animals and the animals affected by 1.2-DMG; ** - statistically significant difference between the parameters of the carcinogenic animals and the animals administered with enterosorbent; *** - statistically significant difference between the parameters of the carcinogenic animals after enterosorption therapy (for 21 days) and the animals administered with cytostatic (for 14 days); * - statistically significant difference between the parameters of the carcinogenic animals (in 7 months) and the animals administered with cytostatic (for 14 days) secondary to enterosorption therapy (for 21 days). 
inflammatory manifestations and control of the studied parameters.

In cases of induced pathological process, a violation of the cytokine profile is observed, as the content of the pro-inflammatory cytokine IL- 6 increases, the content of the anti-inflammatory cytokine IL-4 decreases.

The obtained results point to an imbalance of the cytokine profile with an advantage towards IL-6. It is established that IL- 6 is one of the main inducers of the acute phase response in inflammatory process. Obviously, these changes may evidence of development of chronic inflammation and tumor progression [18].

The system of immunoregulation in the body of the tumor carrier along with the cytokine cascade is followed by changes in the content of CRP. In cases of cytokine profile imbalance in the affected animals, an increase in the CRP content was evidenced. It is established that CRP is an acute marker of inflammation, so the results point towards development and progression of inflammatory processes [19].

Therefore, it has been established that the affection of the experimental animals with 1.2DMG for 7 months leads to an imbalance of the cytokine profile, an increase in the content of acute phase CRP proteins. No significant side effects of the cytostatic Vincristine are evidenced that proves a positive effect of detoxification therapy with the AUR sorbent during the progressive inflammatory process in cases of modeled oncological process.

\section{Conclusions}

A long-term increase in the content of proinflammatory interleukin 6 in addition to reduced production of anti-inflammatory interleukin 4, as well as an increase in C-reactive protein in the rats affected with 1.2-dimethylhydrazine hydrochloride for 30 weeks that evidences development of inflammatory processes in the carcinogenesis body.

After detoxification therapy with AUT-M carbon sorbent a decrease in inflammatory processes activity in the animals with experimental carcinogenesis was present. This is proved by a decrease in the content of proinflammatory interleukin 6, C-reactive protein and an increase in the content of anti-inflammatory interleukin 4.

The positive effect of Vincristine, a cytostatic drug of plant origin, on the activity of inflammatory processes in the rats in cases of experimental carcinogenesis has been established. It has been experimentally proved that this cytostatic has no side effects obviously as a result of previous enterosorption therapy.

\section{Funding}

This research received no external funding.

\section{Conflict of Interest}

The author declares no conflict of interest.

\section{Author Contributions}

Kachur O.I. - resources, investigation, formal analysis, writing - original draft; Fira L.S. conceptualization, formal analysis, writing review \& editing; Lykhatskyi P.H. - conceptualization, project administration, supervision.

\title{
РОЗВИТОК ЗАПАЛЬНИХ ПРОЦЕСІВ У ЩУРІВ ІЗ ІНДУКОВАНИМ КАНЦЕРОГЕНЕЗОМ ТОВСТОЇ КИШКИ ПІСЛЯ ЗАСТОСУВАННЯ ЦИТОСТАТИКУ ВІНКРИСТИН НА ТЛІ ЕНТЕРОСОРБЦІЇ
}

\author{
О.І. Качур, Л.С.Фіра, П.Г.Лихацький \\ ТЕРНОПІЛЬСЬКИЙ НАЦІОНАЛЬНИЙ МЕДИЧНИЙ УНІВЕРСИТЕТ ІМЕНІ І. Я. ГОРБАЧЕВСЬКОГО, \\ ТЕРНОПІЛЬ, УКРАЇНА
}

Вступ. Проблема зростання частоти розвитку злоякісних пухлин товстої кишки - одна з найбільш актуальних у медицини. Об'єктом уваги при вивченні канцерогенезу товстої кишки є стан імунноі системи організму та активація запальних процесів в експериментальних тварин. Перспективним $\epsilon$ проведення хіміотерапії рослинними препаратами на тлі ентеросорційної корекції.

Мета дослідження - оцінити рівень маркерів запалення в сироватці крові експериментальних тварин із хімічно індукованим канцерогенезом та їх динаміку при введенні цитостатика Вінкристин на тлі вуглецевого ентеросорбенту АУТ-М.

Методи дослідження. Дослідженн проводили на білих щурахсамцях. Тваринам моделювали рак товстої кишки шляхом введення 1,2диметилгідразин гідрохлориду в дозі 7,2 мг/кг маси тіла протягом 30ти тижнів. Ентеросорбент АУТ-М вводили інтрагастрально щоденно впродовж 21ї доби після 
моделювання канцерогенезу в дозі 1 мл завису (що відповідає 0,2 г чистої маси препарату) на 100 г маси тіла тварини. Протипухлинний препарат вводили тваринам з індукованим канцерогенезом внутрішньошлунково щоденно протягом 14-ти днів у дозі 0,23 мг/кг маси тіла після 21-денної детоксикачійної терапії. Активність запальних процесів оцінювали за вмістом прозапального інтерлейкіну 6 та протизапального інтерлейкіну 4, Среактивного протеїну в сироватиі крові експериментальних тварин.

Результати. Встановлено, що введення щурам 1,2диметилгідразин гідрохлориду супроводжується зміною цитокінового профілю та вмісту Среактивного протеїну. В уражених тварин спостерігали збільшення вмісту прозапального інтерлейкіну 6, Среактивного протеїну, а також зменшення вмісту протизапального інтерлейкіну 4 в усі терміни дослідення. Застосування ентеросорбенту АУТ сприяло нормалізації цих показників. Введення цитостатика Вінкристин незначно вплинуло на розвиток запальних процесів у досліджуваних тварин.

Висновки. За умов індукованого канцерогенезу встановлено дисбаланс у вмісті про- та протизапальних цитокінів, збільшення вмісту гострофазового С-реактивного протеїну. Відмічено позитивний вплив цитостатика Вінкристин на тлі попередньо проведеної детоксикаційної терапії сорбентом АУТ під час прогресуючого розвитку запальних процесів за умов змодельованого канцерогенезу.

КЛЮЧОВІ СЛОВА: запальні процеси; прозапальні інтерлейкіни; протизапальні інтерлейкіни; сорбент АУТ-М; цитостатик Вінкристин.

\section{Відомості про авторів}

Качур О.І. - асистент кафедри загальної хімії, Тернопільський національний медичнийуніверситет імені І.Я.Горбачевського МОЗ України, Тернопіль, Україна

Фіра Л.С. - доктор біологічних наук, професор, завідувач кафедри фармації ННІ післядипломної освіти,Тернопільський національний медичний університет імені І.Я. Горбачевського МОЗ України, Тернопіль, Україна

Лихацький П.Г. - доктор біологічних наук, професор кафедри медичної біохімії. Тернопільський національний медичний університет імені І.Я. Горбачевського МОЗ України, Тернопіль, Україна

\section{Information about the authors}

Kachur O.I. - assistant professor, Department of General Chemistry, I. Horbachevsky Ternopil National Medical University, Ternopil, Ukraine.

ORCID http://orcid.org/0000-0002-8997-4797, e-mail: kachur_oi@tdmu.edu.ua

Fira L.S. - PhD, DSc, Professor, Head of the Department of Pharmacy of the Academic and Research Institute of Postgraduate Education, I. Horbachevsky Ternopil National Medical University, Ternopil, Ukraine. ORCID http://orcid.org/0000-0002-5325-0973, e-mail: fira@tdmu.edu.ua

Lykhatskyi P.H. - PhD, DSc, Professor of the Department of Medical Biochemistry, I. Horbachevsky Ternopil National Medical University, Ternopil, Ukraine.

ORCID http://orcid.org/0000-0002-0021-782X, e-mail: luhatsky@tdmu.edu.ua

\section{References}

1. Bray F, Ferlay J, Soerjomataram I, et al. Global cancer statistics 2018: Globocan estimates of incidence and mortality worldwide for 36 cancers in 185 countries. CA Cancer J. Clin. 2018;68:394-424.

doi: 10.3322/caac.21492

2. Karmazina IS, Kulinich VA. Correlation analysis of protein metabolism indices at carcinogenesis and inflammation. Natural Almanac.2015;12: 112-8.

3. Zhang X, Liu S, Zhou Y. Circulating levels of C-reactive protein, interleukin- 6 and tumor necrosis factor-a and risk of colorectal adenomas: a metaanalysis. Oncotarget. 2016 Sep 27;7(39):64371-79.

doi: 10.18632 /oncotarget. 11853

4. Gross D, Tolba R. Ethics in animal-based research. Eur. Surg. Res. 2015;55(1-2):43-57. doi: $10.1159 / 000377721$
5. Zhou B, Shu B, Yang J, et al. C-reactive protein, interleukin- 6 and the risk of colorectal cancer: a meta-analysis. Cancer Causes Control, 2014;25(10): 1397-1405.

doi: $10.1007 / \mathrm{s} 10552-014-0445-8$

6. Madsen ML, Due H, Ejskaer N, et al. Aspects of Vincristineinduced neuropathy in hematologic malignancies: A systematic review. Cancer Chemother Pharmacol. 2019; 84:471-85.

doi: 10.1007/s00280-019-03884-5

7. Nikolaev VG, Sakhno LA, Snezhkova EA, Yushko LA. Carbon adsorbents: achievements and perspec- tives. Experimental Oncology, 2011;1: 2-8.

8. Howell CA, Sandeman SR, Zheng Y, et al. New dextran coated activated carbons for medical use. Carbon N. Y. 2016;97:134-46.

doi:10.1016/j.carbon.20.15.09.042 
9. Deryagina VP, Ryzhova NI, Razin AN. Experimental study of the action of Lentinus edodes (Shiitake) on tumor growth in mouse models of transplantation and chemical carcinogenesis. Rossijskij onkologicheskij zhurnal. 2009(1):33-8.

10. Mikhalovsky SV., Sandeman SR, Howell CA, et al. Biomedical Applications of Carbon Adsorbents. In Novel Carbon Adsorbents,2012;21:639-69.

11. Rybolovlev YuR. Dosing of substances for mammals according to the constants of biological activity. Reports of the Academy of Sciences of the USSR, 1979; 247(6): 1513-6.

12. Kozhemiakin YuM, Khromov OS, Filonenko MA, et al.: Scientific and practical recommendations for the maintenance of laboratory animals and work with them. Kyiv - State Pharmacological Center of the Ministry of Health of Ukraine. Kiev, 2002.

13. Gaber W, Azkalany GS, Gheita TA, Mohey A, Sabry R. Clinical significance of serum interleukin- 6 and-174 G/C promoter polymorphism in Rheumatoid arthritis patients. The Egyptian Rheumatologist. 2013 Apr 1;35(2):107-13.

doi: 10.1016/j.ejr.2012.11.002

14. Alybaeva KM, Berdyyarova NA, Mukhamedzhanova NK, et al. Analysis of the quantitative determination of the level of C-reactive protein and procalcitonin in patients with infectious diseases. Bulletin of AGIUV. 2015;1-2:36-40.
15. Okeh U. Statistical problems in medical research. East. Afr. J. Public. Health. 2009;6 (1):1-7. doi: 10.4314/eajph.v6i3.45762

16. Andreichyn SM, Lototska SV, Meretskyi VM. Changes in the indices of cytokine immunity in patients with COPD when using enterosorption. Infectious Diseases, 2015; 3:44-7.

doi: 10.11603/mcch.2410-681x.2015.v17.i3.5063

17. Gaber W, Azkalany GS, Gheita TA, Mohey A, Sabry R. Clinical significance of serum interleukin-6 and $174 \mathrm{G} / \mathrm{C}$ promoter polymorphism in Rheumatoid arthritis patients. The Egyptian Rheumatologist. 2013 Apr 1;35(2):107-13.

doi: 10.1016/j.ejr.12.11.002

18. Godos J, Biondi A, Galvano F, et al. Markers of systemic inflammation and colorectal adenoma risk: Meta-analysis of observational studies. World journal of gastroenterology. 2017 Mar 14;23(10):190919.

doi: 10.3748/wjg.v23.i10.1909

19. Kim MH, Moon HS, Kwon IS, et al. The incidence and risk factors of sessile serrated adenomas in left side colon cancer patients after curative surgery. Medicine. 2020 Jul 17;99(29).

doi: 10.1097/MD.0000000000020799

Received 30 Mar 2020; revised 10 Apr 2020; accepted 02 June 2020.

This is open access article distributed under the Creative Commons Attribution License, which permits unrestricted use, distribution, and reproduction in any medium, provided the original work is properly cited. 